\title{
Tratamiento actual y nuevas terapias contra la infección crónica por el virus de la hepatitis B
}

\section{Current treatment and new therapies against chronic hepatitis B virus infection}

\author{
Simón Gallo E., ${ }^{1}$ Cesar Caraballo C., ${ }^{1}$ Mateo Orozco M., ${ }^{1}$ Octavio Germán Muñoz, MD²
}

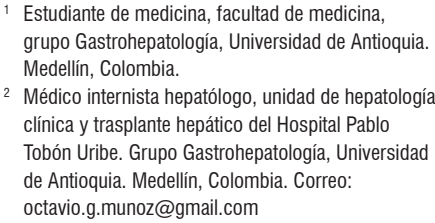

Estudiante de medicina, facultad de medicina grupo Gastrohepatología, Universidad de Antioquia. Medellín, Colombia.

2 Médico internista hepatólogo, unidad de hepatología clínica y trasplante hepático del Hospital Pablo Tobón Uribe. Grupo Gastrohepatología, Universidad de Antioquia. Medellín, Colombia. Correo: octavio.g.munoz@gmail.com

Fecha recibido: $31-05-16$ Fecha aceptado: 21-04-17

\begin{abstract}
Resumen
La infección crónica por el virus de la hepatitis B (VHB) es un grave problema de salud pública a nivel mundial. Sus consecuencias llegan a ser mortales y el tratamiento actual no ofrece curación sino control de la enfermedad. Las principales limitantes para una cura son la dificultad para destruir el ADN circular covalente cerrado (ADNccc) del virus en el núcleo celular y la presencia de material genético viral integrado en el ADN de la célula hospedera. No obstante, hay múltiples frentes de investigación enfocados en encontrar una cura definitiva al potenciar la respuesta inmune del hospedero o al actuar directamente contra el virus y su ciclo de replicación. En este artículo se exponen los principales avances que se han realizado en este campo.
\end{abstract}

\section{Palabras clave}

Virus de la hepatitis B, inmunoterapia, antivirales, hepatitis crónica, cirrosis.

\begin{abstract}
Chronic hepatitis B virus infections are a serious public health problem worldwide. Its consequences can be deadly, and current treatment offers only control of the disease rather than a cure. The main limiting factors for a cure are the difficulty of destroying the cDNA of the virus in the cell nucleus and the presence of viral genetic material integrated into the DNA of the host cell. Multiple fronts of research focus on finding a definitive cure by enhancing the immune response of the host or by acting directly against the virus and its replication cycle. This article presents the main advances that have been made in this field.
\end{abstract}

Keywords

Hepatitis B virus, Immunotherapy, Antiviral Agents, Chronic Hepatitis, Liver Cirrhosis.

\section{INTRODUCCIÓN}

El virus de la hepatitis B (VHB) es un patógeno altamente contagioso y ha infectado a los seres humanos desde hace más de 1500 años (1). A pesar de que hace 50 años Blumberg y colaboradores descubrieron su antígeno de superficie (HBsAg), inicialmente conocido como antígeno de Australia $(2,3)$, y de los diferentes avances en la prevención de su transmisión y opciones de tratamiento supresor. Se calcula que un tercio de la población mundial está infec- tada por este virus (4), de los cuales 240 millones persisten con infección crónica (5), por lo que es la primera causa de hepatitis crónica, cirrosis y carcinoma hepatocelular en el mundo (CHC) (6), generando alrededor de 780000 muertes anuales (5). Debido a su alta morbimortalidad asociada, la infección por el VHB se sitúa como un problema de salud pública a nivel mundial.

El riesgo de desarrollar $\mathrm{CHC}$ durante toda la vida de un sujeto con hepatitis B crónica (HBC) llega a ser hasta del $40 \%$ (7), es la complicación más avanzada y mortal de esta 
enfermedad y, en zonas de alta endemicidad, más del $60 \%$ de los casos de $\mathrm{CHC}$ es atribuible a la $\mathrm{HBC}$ (8).

El VHB posee una amplia distribución mundial. Las zonas de mayor prevalencia ( $>8 \%)$ son el sureste asiático, China, el Medio Oriente, Groenlandia, la cuenca amazónica y la mayoría del territorio africano (9), lugares donde habita el $45 \%$ de la población mundial (10).

La transmisión se da por el contacto parenteral con secreciones contaminadas como sangre, saliva, semen, secreciones cervicales o exudados de heridas. El resultado de la infección y el espectro de la enfermedad varía ampliamente desde los casos asintomáticos hasta la falla hepática aguda, cirrosis y hepatocarcinoma, siendo estas 2 últimas las principales causas de mortalidad asociadas con el virus (11).

El curso natural de la enfermedad dependerá del estado inmunológico del hospedero en el momento de la infección. Así, la transmisión intrauterina, perinatal o en la infancia da como resultado una infección crónica en el 90\% de los casos, que es el escenario más común en las zonas de alta prevalencia. Mientras que la transmisión horizontal durante la adolescencia o adultez tiene como resultado una infección crónica solo en el 5\% de los casos (11).

La infección crónica tiene varias fases dependientes de la interacción entre el virus y el hospedero: inmunotolerancia, inmunorreactividad, portador inactivo y resolución. Estas varían en su duración, no son necesariamente secuenciales y no se dan todas en los sujetos infectados (12).

El principal factor limitante de los tratamientos actuales contra el virus es su incapacidad para destruir el ADN circular covalente cerrado (ADNccc), que se encuentra en el núcleo de los hepatocitos, $(13,14)$ y el ADN viral que se ha integrado al genoma celular del huésped. Esto no permite la curación por el potencial del virus para volver a replicarse una vez se suspende el tratamiento supresor (15). Además, con el tratamiento actual la seroconversión contra el HBsAg rara vez se presenta.

Actualmente, existen múltiples frentes de investigación sobre una potencial cura para la HBC y una gran variedad de medicamentos dirigidos a nuevos blancos moleculares se encuentran en estudio $(16,17)$, los cuales se exponen en este artículo.

\section{CICLO DE REPLICACIÓN VIRAL}

El VHB pertenece a la familia Hepadnaviridae, mide 42 $\mathrm{nm}$, es un virus envuelto y contiene un ADN circular de doble cadena parcial conformado por 3200 kilobases (18). Aunque infecta a otros primates, su principal hospedero es el ser humano y se han identificado 10 genotipos (A-J) con diferente distribución geográfica, comportamiento clínico y respuesta a los tratamientos disponibles (11). Su genoma cuenta con 4 marcos abiertos de lectura superpuestos (overlapping open reading frames $[\mathrm{ORF}]$ ) que codifican las proteínas estructurales y funcionales del virus, cuyos nombres y funciones se presentan en la Tabla 1.

Tabla 1. Marcos abiertos de lectura con sus respectivas proteínas y funciones

\begin{tabular}{|c|c|c|}
\hline $\begin{array}{l}\text { Marco abierto } \\
\text { de lectura } \\
\text { (ORF) }\end{array}$ & $\begin{array}{l}\text { Proteína que } \\
\text { codifica }\end{array}$ & Función \\
\hline$S$ & $\begin{array}{l}\text { Antígeno de } \\
\text { superficie (HBsAg) }\end{array}$ & $\begin{array}{l}\text { Conforma la envoltura viral } \\
\text { y las partículas virales no } \\
\text { infectantes }\end{array}$ \\
\hline \multirow[t]{2}{*}{ C } & $\begin{array}{l}\text { Polipéptido antígeno } \\
\text { core }(\mathrm{HBcAg})\end{array}$ & Constituye la nucleocápside \\
\hline & Antígeno E (HBeAg) & $\begin{array}{l}\text { Inmunomodulación del } \\
\text { hospedero }\end{array}$ \\
\hline$P$ & Polimerasa viral & $\begin{array}{l}\text { Transcriptasa reversa y } \\
\text { ARNasa }\end{array}$ \\
\hline$x$ & Proteína X (HBx) & $\begin{array}{l}\text { Regula la expresión génica } \\
\text { viral y del hospedero } \\
\text { Modula la transducción de } \\
\text { señales intracelulares } \\
\text { Participa en la oncogénesis } \\
\text { hepática }\end{array}$ \\
\hline
\end{tabular}

El VHB ingresa al hepatocito por endocitosis mediante la interacción del HBsAg con el receptor polipéptido cotransportador de sodio-taurocolato (NTCP), con lo que pierde su envoltura $(19,20)$. La nucleocápside es transportada hasta el núcleo donde su ADN parcial es madurado por proteínas celulares a un $\mathrm{ADNccc}$, el cual es un minicromosoma muy estable que va a servir como modelo transcripcional para la ARN polimerasa II del hospedero $(13,21)$. Esta enzima genera 4 copias de ARN mensajero (ARNm) que son traducidas por la maquinaria celular $\mathrm{y}$ así producen las proteínas virales $(11,18)$.

Luego de la traducción, las proteínas de la envoltura y el antígeno $e$ del VHB (HBeAg) tienen como destino el retículo endoplasmático para su posterior secreción. La nucleocápside se ensambla en el citoplasma por la interacción de una copia de ARNm pregenómico, la proteína core y la polimerasa. Inicialmente se forma una nucleocápside inmadura en la que se sintetiza, por la actividad de la transcriptasa reversa de la polimerasa, una cadena negativa de $\mathrm{ADN}$ complementaria al ARNm pregenómico. Una vez se tiene la copia, el ARNm pregenómico es degradado por la actividad de la ribonucleasa tipo $\mathrm{H}$ (ARNasa $\mathrm{H}$ ) de la polimerasa, con lo que permite la síntesis de la cadena positiva de $\mathrm{ADN}$ que queda incompleta en el momento de su entrada al retículo endoplasmático, allí adquiere su envoltura y ulteriormente puede salir como una partícula viral infectante o puede ser transportada de regreso al núcleo 
para reanudar la replicación y mantener así una reserva intranuclear de genomas virales (22).

\section{TRATAMIENTO ACTUAL PARA LA HBC}

Los objetivos del tratamiento son lograr la supresión virológica, remisión bioquímica, mejoría histológica y prevenir el desarrollo de complicaciones como cirrosis, hepatocarcinoma o manifestaciones extrahepáticas. La respuesta al tratamiento se evalúa desde el punto vista bioquímico (normalización de las transaminasas), virológico (supresión de la carga viral), serológico (pérdida del HBeAg o HBsAg y seroconversión a anticuerpo contra el antígeno $e$ de la hepatitis $\mathrm{B}$ [AntiHBe]/anticuerpo contra el antígeno de superficie de la hepatitis viral B [antiHBs]) e histológico con mejoría de la actividad inflamatoria y de fibrosis (23).

La decisión de comenzar el tratamiento se basa en la probabilidad de la respuesta sostenida al tratamiento y el riesgo de morbimortalidad de origen hepático. En general, las indicaciones se basan en 3 criterios:

- Niveles de ADN de VHB en suero

- Niveles de alanina aminotransferasa (ALT) en suero

- Gravedad de la hepatopatía

La Asociación Americana para el Estudio de las Enfermedades Hepáticas (AASLD) en el 2009 (24), la Asociación Asia-Pacífico para el Estudio del Hígado (APASL) en el 2012 (25) y la Asociación Europea para el Estudio del Hígado (EASL) en el 2012 (12) publicaron sus guías de manejo para los pacientes con hepatitis B. En la Tabla 2 se resumen las indicaciones para el inicio del tratamiento de forma comparativa.

Tabla 2. Criterios para iniciar tratamiento en HBC según las diferentes sociedades internacionales

\begin{tabular}{llll}
\hline \multicolumn{1}{c}{ Criterio } & \multicolumn{1}{c}{ EASL 2012 } & AASLD 2009 & APASL 2012 \\
\hline ADN-VHB & & & \\
HBeAg Positivo & $>2000 \mathrm{UI} / \mathrm{mL}$ & $>20000 \mathrm{UI} / \mathrm{mL}$ & $>20000 \mathrm{UI} / \mathrm{mL}$ \\
HBeAg Negativo & $>2000 \mathrm{UI} / \mathrm{mL}$ & $>2000 \mathrm{UI} / \mathrm{mL}$ & $>2000 \mathrm{UI} / \mathrm{mL}$ \\
ALT & $>$ LSN & $>2 \mathrm{LSN}$ & $>2 \mathrm{LSN}$ \\
Biopsia & Considerar & & \\
& solo en grupos & & \\
& seleccionados & & \\
\hline
\end{tabular}

LSN: Límite superior normal.

En los pacientes en la fase de inmunotolerancia y portador inactivo no hay indicación para el inicio de la terapia, dado que la progresión de la enfermedad es baja y el tratamiento puede inducir el riesgo innecesario de resistencia.

A pesar de que en las guías la determinación del inicio de la terapia parece ser simple, en la práctica clínica el proceso es más complejo, debido a que se deben tener en cuenta otras variables relacionadas con el paciente (edad, sexo, genética, entre otros), el medicamento (eficacia, efectos adversos, resistencia, entre otros), la enfermedad hepática (inflamación y fibrosis), cofactores que aumentan el riesgo de fibrosis (consumo de alcohol, obesidad y diabetes), coinfecciones (virus de la inmunodeficiencia humana [VIH], VHB o virus de la hepatitis D [VHD]) y el perfil del VHB (mutación precore-core, carga viral, genotipo).

Actualmente, para el manejo de la HBC se cuenta con 2 tipos de terapias (una encargada de potenciar la respuesta inmune del hospedero contra el virus y otra dirigida directamente contra el virus y su replicación):

1. Interferón pegilado (Peg-IFN) $\alpha-2 a$ y $\alpha-2 b$ : el interferón tiene actividad antiviral e inmunomoduladora, pero tiene muchos efectos adversos: su aplicación es subcutánea (SC), puede exacerbar enfermedades autoinmunes y está contraindicado en falla hepática o cirrosis avanzada. Por estos motivos, su uso está restringido a una población muy reducida. Se considera como terapia finita preferida en pacientes seleccionados: jóvenes, no cirróticos, con carga viral baja y marcada actividad inflamatoria. La tasa de seroconversión del HBeAg es del 29\%-32\% y la pérdida del HBsAg es de 3\%-7\% $(26,27)$.

2. Análogos nucleósidos/nucleótidos (AN): inhiben la transcripción reversa del ARN pregenómico a ADN $y$ no tienen efecto sobre el $\mathrm{ADNccc}$; es por esto que suprimen la replicación, pero no curan la infección, por lo que el tratamiento es a largo plazo y existe el riesgo de recaídas luego de su suspensión. Actualmente, hay 5 medicamentos disponibles: lamivudina, telbivudina, entecavir, adefovir y tenofovir.

Los AN se caracterizan por diferentes patrones de potencia y resistencia. En general, actualmente no se usa la lamivudina de primera línea por su alta tasa de resistencia y se emplea en algunos casos seleccionados donde se prevé que la terapia durará corto tiempo, como en la hepatitis aguda grave, falla hepática aguda, profilaxis de trasmisión vertical durante el embarazo o en los pacientes que serán inmunosuprimidos para evitar la reactivación. La telbivudina y adefovir no se usan de primera línea porque tienen menor potencia y posibilidad de resistencia. Ahora se prefiere iniciar el tratamiento con los AN de alta potencia y baja resistencia, como el entecavir o tenofovir.

Un curso de un año de $\mathrm{AN}$ en pacientes $\mathrm{HBeAg}$ positivos resulta en la supresión del ADN viral hasta concentraciones indetectables entre el 21\%-76\% de los pacientes, normalización de las transaminasas hasta el 77\%, seroconversión del HBeAg entre el 12\%-22\% y pérdida del HBsAg del 0\%-3\%. La extensión del tratamiento hasta 5 años aumenta la seroconversión del 
HBeAg hasta el $48 \%$ y la tasa de pérdida del HBsAg hasta el $10 \%(28)$.

\section{NUEVAS TERAPIAS DIRIGIDAS A POTENCIAR LA RESPUESTA INMUNE DEL HOSPEDERO}

Las bajas tasas de curación probablemente se deban a un defecto en la reconstitución de una respuesta inmune adaptiva específica contra el virus (29). Es por esto que los esfuerzos científicos se han centrado en encontrar nuevos blancos terapéuticos que logren potenciar la respuesta inmune contra la infección. En los últimos años, se ha logrado un gran avance en este campo, lo que ha permitido determinar potenciales terapias para la infección crónica por VHB, entre las que se encuentran los agonistas de los receptores de reconocimiento de patrones (PRR), timosina $\alpha-1$ ( $\mathrm{T} \alpha 1)$, bloqueo de señales inmunoinhibidoras (PD-1) y terapia basada en células asesinas naturales (NK).

\section{Agonistas de los PRR}

Los PRR son proteínas que permiten detectar patrones moleculares asociados con microorganismos patógenos (PAMP) y están presentes en distintos grupos celulares como los hepatocitos y las células del sistema inmune innato. Entre los principales PRR se encuentran los receptores tipo Toll (TLR), scavenger, lectinas tipo C y receptores tipo NOD (NLR).

El VHB fue por mucho tiempo considerado como un virus sigiloso, pues se creía que inducía una pobre respuesta inmune innata durante la fase temprana de la infección. Sin embargo, estudios recientes han revelado que el VHB puede ser reconocido por los PRR (30), al provocar una respuesta mediada por citoquinas que controla la replicación viral (31). Esto ha sido evidenciado en las células de Kupffer, las células estrelladas y las sinusoidales (32). El objetivo de la terapia con agonistas de los PRR es potenciar la respuesta antiviral de las citoquinas, principalmente de los interferones (IFN) tipos I y III (33) y, así, lograr una respuesta inmune adaptativa específica que perdure en el tiempo. Varios estudios han mostrado que la estimulación de células que expresan TLR 7, TLR 9 y TLR 3 en el hígado pueden producir la respuesta inmune innata mencionada anteriormente $(34,35)$.

El receptor TLR 7 es expresado principalmente por las células dendríticas y los linfocitos $\mathrm{B}$, con el que se reconoce el ARN viral (36). El GS 9620 es un agonista del TLR 7 que se encuentra en ensayos clínicos en fase II (37). Este medicamento que se administra por vía oral (VO) ha mostrado efectos antivirales contra el VHB suprimiendo el ADN del virus en el suero y en el hígado de chimpancés infectados. En este estudio, se trató por 8 semanas a 3 chimpancés con
$\mathrm{HBC}$, en los que se vio una diminución de la carga viral persistente y una reducción del $50 \%$ en los niveles séricos del HBsAg y HBeAg (38). Estos estudios han sido replicados en marmotas y se encontraron resultados similares (39). Los estudios de farmacocinética y farmacodinamia en personas sanas sugieren que dosis bajas de GS 9620 inducen una respuesta inmune innata dependiente del IFN-I (40). También se ha reportado que 1 o 2 dosis bajas administradas 1 vez a la semana son seguras y bien toleradas. Sin embargo, los ensayos clínicos no han mostrado evidencia de eficacia clínica en términos de disminución del ADN del VHB (37).

Un agonista de TLR 3 aplicado por vía parenteral logró amplificar la respuesta inmune y acelerar la depuración del VHB en ratones gracias al aumento de IFN-I y II (41). Otro estudio que utilizó agonista de TLR 9 en ratones logró la inducción de un agregado de células mieloides intrahepáticas que generaron una expansión de linfocitos T citotóxicos en el hígado (iMATE) (42), con lo que se logró reducir la replicación del VHB en los hepatocitos.

La proteína transmembrana estimuladora de genes de IFN (STING) es una proteína adaptadora de múltiples receptores citoplasmáticos y también actúa como un PRR que reconoce segundos mensajeros bacterianos (43). La estimulación de STING ha mostrado un aumento significativo del IFN-I con supresión de la replicación viral del VHB en los hepatocitos de ratones infectados (32), lo que abre un nuevo campo de estudio terapéutico.

\section{Ta1}

La timosina alfa $(\mathrm{T} \alpha)$ es una proteína con actividad inmunomoduladora producida por el timo. Zadaxin ${ }^{\circledast}(\mathrm{T} a 1)$ es una proteína sintética basada en la timosina natural (44). En estudios in vitro ha mostrado que aumenta la producción y maduración de los linfocitos $\mathrm{T}$, estimulando la producción de citoquinas Th1 como el IFN-Y y la interleucina tipo 2 (IL-2). También ha mostrado capacidad para activar las células NK y su actividad citotóxica (45).

Un ensayo clínico aleatorizado realizado en China mostró que Zadaxin ${ }^{\circledast}$ es seguro, bien tolerado y eficaz como inhibidor de la replicación del VHB. Además, los pacientes tratados con este medicamento tuvieron más seroconversión comparados con los que fueron tratados con IFN- $\alpha$ (46). Otro estudio demostró que pacientes $\mathrm{HBeAg}$ negativos tratados con Zadaxin ${ }^{\circledast}$ más IFN- $\alpha$ tuvieron una respuesta inmunológica más fuerte que aquellos tratados con una combinación de lamivudina más IFN- $\alpha$ o IFN solo (47). Igualmente, en pacientes $\mathrm{HBeAg}$ positivos, la terapia con Zadaxin ${ }^{\circledast}$ más lamivudina fue más efectiva en aumentar la respuesta inmune y la seroconversión del HBeAg que la monoterapia con lamivudina (48). Está terapia también ha tenido resultados en contra, como resultado de un estudio 
la combinación de Ta1 con Peg-INF $\alpha$-2a no fue superior a este en monoterapia en pacientes con $\mathrm{HBC}$ y $\mathrm{HBeAg}$ positivo (49), por lo que se requiere más investigación que avale este tipo de terapia.

\section{Bloqueo de señales inmunoinhibidoras (PD-1)}

En la infección crónica por VHB se ha observado una falta de respuesta contra el virus mediada por los linfocitos $\mathrm{T}$ específicos debido a un fenómeno conocido como agotamiento, el cual se caracteriza por la escasez o ausencia de células $\mathrm{T}$ específicas contra el VHB asociado con pobre actividad citotóxica, deterioro en la producción de citoquinas y aumento en la expresión de receptores coinhibitorios, como la proteína de muerte celular programada 1 (PD-1), antígeno 4 asociado al linfocito T citotóxico (CTLA-4), proteína 3 del gen de activación de linfocitos (LAG 3), entre otros (50). Este fenómeno es mantenido por la presencia de un microambiente de citoquinas inmunosupresoras, como IL-10 y el factor de crecimiento transformante beta (TGF- $\beta$ ) producidas por los linfocitos $\mathrm{T}$ reguladores encontrados en gran cantidad en el hígado de pacientes con $\operatorname{HBC}(51,52)$.

Recientemente se ha estudiado el bloqueo de estos receptores por medio de anticuerpos específicos como blanco terapéutico en el cáncer, con lo que se encontró un aumento en la supervivencia (53). El cáncer y la infección crónica por VHB tienen muchas similitudes desde el punto de vista inmunológico, lo que ha permitido iniciar estudios terapéuticos utilizando el bloqueo de las señales inmunoinhibitorias, principalmente la PD-1. Zhang y colaboradores encontraron que en pacientes con VHB el 70\% de los linfocitos $\mathrm{T}$ específicos para el virus eran positivos para PD-1 (54). Varios estudios han sido publicados al respecto, uno de ellos realizado en ratones con infección crónica por VHB demostró que los anticuerpos anti-PD-1 lograron revertir la disfunción inmune y ayudaron en cierta medida a depurar el virus (60\% de negatividad para HBsAg en comparación con $20 \%$ en los controles) (55). Actualmente los anticuerpos anti PD-1 se utilizan para el cáncer y se encuentran en ensayos clínicos para la hepatitis crónica por VHC (56). A la fecha de hoy no hay ningún ensayo clínico donde se evalúe la utilidad de los anticuerpos anti-PD-1 en humanos; sin embargo, los estudios con otras enfermedades similares al VHB hacen que sea cuestión de tiempo el avance de la investigación en este campo.

\section{Terapia basada en células NK}

Las células NK hacen parte del sistema inmune innato, se encuentran en gran proporción en el hígado humano y son cruciales para la defensa contra infecciones virales (57).
Para esto cuentan con al menos 3 mecanismos: aumento de gránulos citolíticos que lisan las células infectadas, apoptosis de las células marcadas a través de receptores de superficie y aumento de citoquinas específicas. Estas células juegan un papel fundamental en la respuesta temprana contra el VHB pues, a través de la secreción de IFN- $\gamma$, ayudan a reducir la carga viral (58). En pacientes infectados crónicamente por $\mathrm{VHB}$ se ha visto que la función citolítica de las NK se mantiene, aunque la activación y secreción de IFN- $\gamma$ y TNF- $\alpha$ está fuertemente afectada (59). En un estudio, la restauración de la capacidad de las NK de producir citoquinas a través de la reducción de la carga viral logró contribuir a la depuración del virus (60). El desarrollo de una terapia que le devuelva la capacidad a las células NK de producir citoquinas puede ser una estrategia para curar a los pacientes con VHB crónica.

\section{Vacunas terapéuticas}

Las diferentes vacunas que se han estudiado contienen varios productos tanto inmunes como del virus, entre los cuales se encuentran el HBsAg, complejos inmunes HBsAg-antiHBs, $\mathrm{ADN}$ que expresa $\mathrm{HBsAg}$ por medio de plásmidos y vacuna de células $\mathrm{T}$.

Las investigaciones que las tuvieron como objeto de estudio han demostrado una disminución en la viremia, seroconversión del $\mathrm{HBeAg}$ y potenciación de respuestas de células $\mathrm{T}$ específicas contra el VHB. Sin embargo, estos cambios fueron insuficientes para el control de la infección crónica por el VHB, por lo que se estudiaron las terapias combinadas con antivirales después del tratamiento antiviral hasta lograr cargas virales indetectables o concomitantemente. Los resultados fueron alta tolerabilidad a la vacuna y potenciación de la respuesta inmune específica asociada con alta supresión de la viremia, pero con aumento del $\mathrm{ADN}$ viral al descontinuarla. No se evidenció disminución en el riesgo de recaídas, ni aumento en la seroconversión del HBsAg (61).

DV601 (Dynavax) y GS4774 (Gilead Sciences) son 2 ejemplos de vacunas que expresan secuencias de antígenos virales en proteínas de fusión y se encuentran en ensayos de primera fase (17).

\section{NUEVAS TERAPIAS DIRIGIDAS DIRECTAMENTE CONTRA EL VIRUS Y SU REPLICACIÓN}

En los últimos años también se ha logrado un gran avance en este campo, lo que ha permitido determinar potenciales terapias con este fin, entre las que se encuentran los inhibidores de la entrada, agonistas del receptor de linfotoxina- $\beta$ (LT $\beta R$ ), ARN pequeño de interferencia (siRNA), secuencias guía externas (EGS), enzimas de escisión de ADNccc e inhibidores de la ribonucleasa $\mathrm{H}$ (RNAsa $\mathrm{H})$. 


\section{Inhibidores de la entrada}

Lograr inhibir la entrada del virus en los hepatocitos tendría implicaciones terapéuticas significativas y puede lograrse neutralizando las proteínas de la superficie virales presentes en su envoltura, lo que inhibe la unión mediada por proteoglicanos de heparán-sulfato (PGHS) o bloquean su receptor.

El primer inhibidor de la entrada del virus y, actualmente, el único clínicamente aprobado es la inmunoglobulina (Ig) de la hepatitis $B$, que disminuye significativamente el riesgo de adquirir la infección ulterior a una exposición. A partir de su uso, muchos anticuerpos monoclonales con la región $S$ o pre-S como blanco molecular han sido desarrollados, pero ninguno ha sido aprobado para el tratamiento (62).

Para inhibir la unión mediada por PGHS, se ha descrito la utilidad de la heparina y la suramina, un derivado de la urea, las cuales se unen a las proteínas de superficie del virus evitando su interacción con los PGHS. La evidencia se limita a estudios in vitro para ambas e in vivo en patos para la suramina (63).

El polipéptido cotransportador de sodio taurocolato (NTCP) es un transportador de ácidos biliares que solo se expresa en la membrana basolateral de los hepatocitos. Recientemente fue identificado como el receptor para el VHB y esto lo hace un blanco molecular ideal para nuevos esfuerzos terapéuticos. Para el bloqueo del NTCP se está estudiando el myrcludex $\mathrm{B}$, el cual es un lipopéptido derivado del dominio pre-S1 de la envoltura del VHB, por lo que puede unirse al NTCP e inhibir la unión del VHB y, por tanto, su entrada. Puede prevenir la propagación viral desde células infectadas in vivo y reduce la amplificación del ADNccc en hepatocitos recién infectados. Petersen y colaboradores demostraron que es capaz de prevenir la infección por el VHB en cultivos de hepatocitos y ratones humanizados, así como el establecimiento de la infección por VHD. Entre sus efectos adversos está la inhibición del transporte de ácidos biliares (64). Otros inhibidores conocidos del NTCP son la ciclosporina A y B, ezetimiba, irbesartán, ritonavir, bosentán, propranolol, entre otros.

\section{Agonistas del LT $\beta$ R}

Mediante anticuerpos específicos para el LT $\beta R$ se ha evidenciado en cultivos celulares degradación del ADNccc mediante mecanismos independientes de IFN y sin el uso directo de otras citoquinas. $\mathrm{Al}$ unirse al receptor, inician un proceso de desaminación selectiva del ADNccc, lo que ocasiona la degradación del mismo por endonucleasas de la familia enzima editora de la apolipoproteína B mediante ARNm semejante al polipéptido catalítico 3 (APOBEC3). La acción selectiva de estas sobre el $\mathrm{ADNccc}$ se debe a que interactúan directamente con la proteína core, explicando así por qué no causa daño en el genoma del hepatocito hospedero (61).

\section{SIRNA}

Los ARN pequeños de interferencia son secuencias cortas que no codifican y que están presentes en las células regulando la expresión postranscripcional de determinados genes. Debido a que el genoma del VHB es compacto y se superpone, el uso de los siRNA es alentador y algunos estudios demostraron que, dirigidos a las transcripciones de core o una proteína viral de la hepatitis B ( $\mathrm{HBx})$, detienen la expresión genética del VHB que se evidencia con la disminución significativa de $\mathrm{HBsAg}, \mathrm{HBeAg}, \mathrm{ARN}$ y $A D N$ viral $(61,65,66)$. Un ensayo clínico fase II de asignación aleatoria y doble ciego está actualmente reclutando participantes con infección crónica por VHB para evaluar la eficacia de un medicamento denominado ARC-520, que contiene 2 siRNA contra este virus (identificador en clinicaltrials.gov: NCT02065336).

\section{EGS}

Las EGS son secuencias de oligonucleótidos complementarios a un ARNm específico. Después de unirse a su ARN complementario, dirige a la ribonucleasa $P$ para destruirlo y así inhibe la síntesis de proteínas, en este caso virales. Algunos estudios en cultivos celulares han demostrado la capacidad de estas EGS para disminuir hasta 200000 veces la concentración de $\mathrm{ADN}$ viral $(67,68)$.

\section{Enzimas de escisión de ADNccc}

- Nucleasas con dedos de zinc (ZFN): en el interior del hepatocito 2 ZFN reconocen, cada uno, partes opuestas de una secuencia del ADN viral y escinden la doble cadena. Es por esto que teóricamente unos ZFN diseñados para atacar el ADN del VHB no tendrían efecto sobre el genoma del hospedero. 2 estudios in vitro han demostrado que mediante este mecanismo se disminuye la concentración de $\mathrm{ARN}$ pregenómico y $\mathrm{ADNccc}$ significativamente $(69,70)$. No obstante, el principal reto es lograr encontrar un mecanismo de entrega eficiente a los hepatocitos (66).

- Efectores similares al activador de transcripción y sus derivados (TALEN): con una estructura similar a las ZFN, los TALEN cuentan con una secuencia de 33 a 35 aminoácidos que en la posición 12 y 13 reconocen un segmento específico del ADNccc. A diferencia de los ZFN, los TALEN escinden el ADNccc como monómeros. Estudios in vitro y en ratones han demostrado su 
eficacia (71), por lo que si se lograse que ingresaran a los hepatocitos in vivo, los TALEN podrían ser una cura definitiva para la infección por VHB (66).

- Repeticiones palindrómicas cortas agrupadas y regularmente interespaciadas/sistema asociado a CRISPR (CRISPR/cas): es un sistema bacteriano con actividad nucleasa que está involucrado en la defensa contra bacteriófagos y plásmidos. Está compuesto por los genes cas y ARN no codificantes que determinan la especificidad del sistema. Recientemente se ha utilizado como un método de edición genómica y al sintetizar ARN guías no codificantes específicas es posible ocasionar rompimiento de la doble cadena de $\mathrm{ADN}$ en secuencias deseadas. Recientemente se ha demostrado su efectividad para disminuir la replicación del VHB in vitro, lo que abre las puertas a futuras investigaciones clínicas sobre este grupo de medicamentos contra el virus (72).

\section{Inhibidores RNAsa H}

Las RNAsa $\mathrm{H}$ escinden el ARN cuando está unido al ADN, remueven los cebadores durante la síntesis de $\mathrm{ADN}$, contribuyen a la destrucción de errores fallidos de transcripción y son necesarias para la transcripción reversa de genomas virales como el del VHB. La inhibición de esta enzima está ampliamente conocida como parte del tratamiento contra el VIH, pero poco se ha estudiado sobre su uso como tratamiento para el VHB, con algunos estudios in vitro que sugieren su efectividad $(43,73)$. El objetivo de los medicamentos que comparten este mecanismo de acción es suprimir la replicación viral para detener el reaprovisionamiento de $\mathrm{ADNccc}$ en el hígado, lo que permite eliminar las células infectadas por el sistema inmune o por otro medicamento concomitante $(66,74)$.

\section{CONCLUSIÓN}

Es claro que en las últimas décadas se han logrado avances significativos en la identificación del ciclo celular del VHB $y$ en su tratamiento. A pesar de esto, la morbimortalidad asociada continúa siendo alta y el tratamiento, poco más que una medida de control.

Actualmente existen múltiples frentes de investigación en la búsqueda de nuevas terapias para la HBC, con el fin de encontrar un tratamiento curativo más que supresor de la enfermedad. El avance no se limita solo al descubrimiento y aplicabilidad clínica de nuevas moléculas terapéuticas sino también a la identificación de enzimas implicadas en la replicación viral y celular o defectos de la respuesta inmune del hospedero que podrían tener un papel clave para el desarrollo de nuevos medicamentos con potencial curativo.
Con múltiples medicamentos en fases de estudio molecular, in vitro, en modelos animales o clínico, es solo cuestión de tiempo para que el arsenal terapéutico para la HBC sea cada vez más numeroso y nos acerquemos paulatinamente a una cura definitiva.

\section{Apoyo financiero}

No hubo fuente de apoyo financiero.

\section{REFERENCIAS}

1. Zhou Y, Holmes EC. Bayesian estimates of the evolutionary rate and age of hepatitis B virus. J Mol Evol. 2007;65(2):197205. Doi: https://doi.org/10.1007/s00239-007-0054-1

2. Blumberg BS, Alter HJ, Visnich S. A «new» antigen in leukemia sera. JAMA.1965;191:541-6. Doi: https://doi. org/10.1001/jama.1965.03080070025007

3. Blumberg BS, Gerstley BJ, Hungerford DA, et al. A serum antigen (Australia antigen) in Down's syndrome, leukemia, and hepatitis. Ann Intern Med. 1967;66(5):924-31. Doi: https://doi.org/10.7326/0003-4819-66-5-924 https:// doi.org/10.7326/0003-4819-66-5-1040_2

4. Araujo NM. Hepatitis B virus intergenotypic recombinants worldwide: An overview. Infect Genet Evol. 2015;36:50010. Doi: https://doi.org/10.1016/j.meegid.2015.08.024

5. World Health Organization [internet]. Hepatitis B. Fact sheet No. 204. WHO; 2016 [acceso el 5 de mayo de 2016]. Disponible en: http://www.who.int/mediacentre/factsheets/fs204/en/

6. D'Souza R, Foster GR. Diagnosis and treatment of chronic hepatitis B. J R Soc Med. 2004;97(7):318-21. Doi: https:// doi.org/10.1258/jrsm.97.7.318

7. Chen C-J, Chen D-S. Interaction of hepatitis B virus, chemical carcinogen, and genetic susceptibility: multistage hepatocarcinogenesis with multifactorial etiology. Hepatology. 2002;36(5):1046-9. Doi: https://doi.org/10.1053/ jhep.2002.37084

8. Di Bisceglie AM. Hepatitis B and hepatocellular carcinoma. Hepatology. 2009;49(5 Suppl): S56-60. Doi: https://doi. org/10.1002/hep.22962

9. Hou J, Liu Z, Gu F. Epidemiology and prevention of hepatitis B virus infection. Int J Med Sci. 2005;2(1):50-7. Doi: https://doi.org/10.7150/ijms.2.50

10. Aljarbou AN. The emergent concern of hepatitis B globally with special attention to Kingdom of Saudi Arabia. Int J Health Sci. 2013;7(3):333-40. Doi: https://doi. org/10.12816/0006062

11. Thio CL, Hawkins C. Hepatitis B virus and hepatitis delta virus. En: Bennett OE, Dolin R, Blaser MJ (editores). Mandell, Douglas, and Bennett's Principles and Practice of Infectious Diseases. 8.a edición. Elsevier; 2015. p. 1815-39.

12. European Association For The Study Of The Liver. EASL clinical practice guidelines: Management of chronic hepa- 
titis B virus infection. J Hepatol. 2012;57(1):167-85. Doi: https://doi.org/10.1016/j.jhep.2012.02.010

13. Kumar R, Pérez-Del-Pulgar S, Testoni B, et al. Clinical relevance of the study of hepatitis B virus covalently closed circular DNA. Liver Int. 2016;36 Suppl 1:72-7. Doi: https:// doi.org/10.1111/liv.13001

14. Raimondo G, Allain J-P, Brunetto MR, et al. Statements from the Taormina expert meeting on occult hepatitis B virus infection. J Hepatol. 2008;49(4):652-7. Doi: https:// doi.org/10.1016/j.jhep.2008.07.014

15. Chemin I, Zoulim F. Hepatitis B virus induced hepatocellular carcinoma. Cancer Lett. 2009;286(1):52-9. Doi: https://doi.org/10.1016/j.canlet.2008.12.003

16. Alaluf MB, Shlomai A. New therapies for chronic hepatitis B. Liver Int. 2016;36(6):775-82. Doi: https://doi. org/10.1111/liv.13086

17. Block TM, Rawat S, Brosgart CL. Chronic hepatitis B: a wave of new therapies on the horizon. Antiviral Res. 2015;121:69-81. Doi: https://doi.org/10.1016/j.antiviral.2015.06.014

18. Gish RG, Given BD, Lai C-L, et al. Chronic hepatitis B: virology, natural history, current management and a glimpse at future opportunities. Antiviral Res. 2015;121:47-58. Doi: https://doi.org/10.1016/j.antiviral.2015.06.008

19. Yan H, Li W. Sodium taurocholate cotransporting polypeptide acts as a receptor for hepatitis B and D virus. Dig Dis Basel Switz. 2015;33(3):388-96. Doi: https://doi. org/10.1159/000371692

20. Li W. The hepatitis B virus receptor. Annu Rev Cell Dev Biol. 2015;31:125-47. Doi: https://doi.org/10.1146/annurev-cellbio-100814-125241

21. Lucifora J, Protzer U. Attacking hepatitis B virus cccDNA-the holygrailtohepatitisB cure.JHepatol.2016;64(1 Suppl):S41-48. Doi: https://doi.org/10.1016/j.jhep.2016.02.009

22. Ganem D, Prince AM. Hepatitis B virus infection-natural history and clinical consequences. $\mathrm{N}$ Engl $\mathrm{J}$ Med. 2004;350(11):1118-29. Doi: https://doi.org/10.1056/ NEJMra031087

23. Yapali S, Talaat N, Lok AS. Management of hepatitis B: our practice and how it relates to the guidelines. Clin Gastroenterol Hepatol. 2014;12(1):16-26. Doi: https:// doi.org/10.1016/j.cgh.2013.04.036

24. Lok ASF, McMahon BJ. Chronic hepatitis B: update 2009. Hepatology. 2009;50(3):661-2. Doi: https://doi. org $/ 10.1002 /$ hep. 23190

25. Liaw Y-F, Kao J-H, Piratvisuth T, et al. Asian-Pacific consensus statement on the management of chronic hepatitis B: a 2012 update. Hepatol Int. 2012;6(3):531-61. Doi: https:// doi.org/10.1007/s12072-012-9365-4

26. Janssen HLA, van Zonneveld M, Senturk H, et al. Pegylated interferon $a l f a-2 b$ alone or in combination with lamivudine for HBeAg-positive chronic hepatitis B: a randomised trial. Lancet. 2005;365(9454):123-9. Doi: https://doi. org/10.1016/S0140-6736(05)17701-0

27. Lau GKK, Piratvisuth T, Luo KX, et al. Peginterferon Alfa-2a, lamivudine, and the combination for HBeAg-positive chro- nic hepatitis B. N Engl J Med. 2005;352(26):2682-95. Doi: https://doi.org/10.1056/NEJMoa043470

28. Chang T-T, Lai C-L, Kew Yoon S, et al. Entecavir treatment for up to 5 years in patients with hepatitis B e antigen-positive chronic hepatitis B. Hepatology. 2010;51(2):422-30. Doi: https://doi.org/10.1002/hep.23327

29. Bertoletti A, Tan AT, Gehring AJ. HBV-specific adaptive immunity. Viruses. 2009;1(2):91-103. Doi: https://doi. org $/ 10.3390 / \mathrm{v} 1020091$

30. Shlomai A, Schwartz RE, Ramanan V, et al. Modeling host interactions with hepatitis B virus using primary and induced pluripotent stem cell-derived hepatocellular systems. Proc Natl Acad Sci USA. 2014;111(33):12193-8. Doi: https://doi.org/10.1073/pnas.1412631111

31. Takeuchi O, Akira S. Pattern recognition receptors and inflammation. Cell. 2010;140(6):805-20. Doi: https://doi. org/10.1016/j.cell.2010.01.022

32. Guo F, Han Y, Zhao X, et al. STING agonists induce an innate antiviral immune response against hepatitis $B$ virus. Antimicrob Agents Chemother. 2015;59(2):1273-81. Doi: https://doi.org/10.1128/AAC.04321-14

33. Luangsay S, Ait-Goughoulte $\mathrm{M}$, Michelet $\mathrm{M}$, et al. Expression and functionality of Toll- and RIG-like receptors in HepaRG cells. J Hepatol. 2015;63(5):1077-85. Doi: https://doi.org/10.1016/j.jhep.2015.06.022

34. DalodM,Chelbi R, Malissen B, etal.Dendritic cell maturation: functional specialization through signaling specificity and transcriptional programming. EMBO J. 2014;33(10):110416. Doi: https://doi.org/10.1002/embj.201488027

35. van der Aa E, van Montfoort N, Woltman AM. BDCA3 $(+)$ CLEC9A $(+)$ human dendritic cell function and development. Semin Cell Dev Biol. 2015;41:39-48. Doi: https:// doi.org/10.1016/j.semcdb.2014.05.016

36. O’Neill AK, Niederst MJ, Newton AC. Suppression of survival signalling pathways by the phosphatase PHLPP. FEBS J. 2013;280(2):572-83. Doi: https://doi.org/10.1111/ j.1742-4658.2012.08537.x

37. Gane EJ, Lim Y-S, Gordon SC, et al. The oral Toll-like receptor-7 agonist GS-9620 in patients with chronic hepatitis B virus infection. J Hepatol. 2015;63(2):320-8. Doi: https:// doi.org/10.1016/j.jhep.2015.02.037

38. Lanford RE, Guerra B, Chavez D, et al. GS-9620, an oral agonist of Toll-like receptor-7, induces prolonged suppression of hepatitis $B$ virus in chronically infected chimpanzees. Gastroenterology. 2013;144(7):1508-17, 1517.e1-10.

39. Menne S, Tumas DB, Liu KH, et al. Sustained efficacy and seroconversion with the Toll-like receptor 7 agonist GS-9620 in the Woodchuck model of chronic hepatitis B. J Hepatol. 2015;62(6):1237-45. Doi: https://doi. org/10.1016/j.jhep.2014.12.026

40. Fosdick A, Zheng J, Pflanz S, Frey CR, Hesselgesser J, Halcomb RL, et al. Pharmacokinetic and pharmacodynamic properties of GS-9620, a novel Toll-like receptor 7 agonist, demonstrate interferon-stimulated gene induction without detectable serum interferon at low oral doses. J 
Pharmacol Exp Ther. 2014;348(1):96-105. Doi: https:// doi.org/10.1124/jpet.113.207878

41. Wu J, Huang S, Zhao X, et al. Poly(I:C) treatment leads to interferon-dependent clearance of hepatitis B virus in a hydrodynamic injection mouse model.J Virol. 2014;88(18):1042131. Doi: https://doi.org/10.1128/JVI.00996-14

42. Huang L-R, Wohlleber D, Reisinger F, et al. Intrahepatic myeloid-cell aggregates enable local proliferation of CD8 $(+)$ $\mathrm{T}$ cells and successful immunotherapy against chronic viral liver infection. Nat Immunol. 2013;14(6):574-83. Doi: https://doi.org/10.1038/ni.2573

43. Cai CW, Lomonosova E, Moran EA, et al. Hepatitis B virus replication is blocked by a 2 -hydroxyisoquinoline- $1,3(2 \mathrm{H}$, $4 \mathrm{H}$ )-dione (HID) inhibitor of the viral ribonuclease $\mathrm{H}$ activity. Antiviral Res. 2014;108:48-55. Doi: https://doi. org/10.1016/j.antiviral.2014.05.007

44. Tsai S-L, Sheen I-S, Chien R-N, et al. Activation of Th1 immunity is a common immune mechanism for the successful treatment of hepatitis B and C: tetramer assay and therapeutic implications. J Biomed Sci. 2003;10(1):120-35. Doi: https://doi.org/10.1007/BF02256004

45. Grimm D, Thimme R, Blum HE. HBV life cycle and novel drug targets. Hepatol Int. 2011;5(2):644-53. Doi: https:// doi.org/10.1007/s12072-011-9261-3

46. You J, Zhuang L, Tang BZ, et al. A randomized controlled clinical trial on the treatment of Thymosin al versus interferonalpha in patients with hepatitis B. World J Gastroenterol. 2001;7(3):411-4. Doi: https://doi.org/10.3748/wjg.v7.i3.411

47. Saruc M, Ozden N, Turkel N, et al. Long-term outcomes of thymosin-alpha 1 and interferon alpha-2b combination therapy in patients with hepatitis $\mathrm{B}$ e antigen $(\mathrm{HBeAg})$ negative chronic hepatitis B. J Pharm Sci. 2003;92(7):1386-95. Doi: https://doi.org/10.1002/jps.10401

48. Zhang Y-Y, Chen E-Q, Yang J, et al. Treatment with lamivudine versus lamivudine and thymosin alpha- 1 for e antigenpositive chronic hepatitis B patients: a meta-analysis. Virol J. 2009;6:63. Doi: https://doi.org/10.1186/1743-422X-6-63

49. Kim BH, Lee Y-J, Kim W, et al. Efficacy of thymosin $\alpha-1$ plus peginterferon $\alpha-2 a$ combination therapy compared with peginterferon $\alpha$-2a monotherapy in $\mathrm{HBeAg}$-positive chronic hepatitis B: a prospective, multicenter, randomized, openlabel study. Scand J Gastroenterol. 2012;47(8-9):1048-55. Doi: https://doi.org/10.3109/00365521.2012.694902

50. Brahmania M, Feld J, Arif A, et al. New therapeutic agents for chronic hepatitis B. Lancet Infect Dis. 2016;16(2):e10-21. Doi: https://doi.org/10.1016/S1473-3099(15)00436-3

51. Rehermann B, Bertoletti A. Immunological aspects of antiviral therapy of chronic hepatitis B virus and hepatitis $\mathrm{C}$ virus infections. Hepatology. 2015;61(2):712-21. Doi: https://doi.org/10.1002/hep.27323

52. Ye B, Liu X, Li X, et al. T-cell exhaustion in chronic hepatitis B infection: current knowledge and clinical significance. Cell Death Dis. 2015;6:e1694. Doi: https://doi.org/10.1038/ cddis. 2015.42

53. Wolchok JD, Kluger $\mathrm{H}$, Callahan $\mathrm{MK}$, et al. Nivolumab plus ipilimumab in advanced melanoma. $\mathrm{N}$ Engl $\mathrm{J}$ Med.
2013;369(2):122-33. Doi: https://doi.org/10.1056/ NEJMoa 1302369

54. Zhang W-J, Peng C-H, Zheng S-S. Programmed death 1 and programmed death ligand 1 expressions in patients with chronic hepatitis B. Hepatobiliary Pancreat Dis Int. 2013;12(4):394-9. Doi: https://doi.org/10.1016/S14993872(13)60061-2

55. Tzeng H-T, Tsai H-F, Liao H-J, et al. PD-1 blockage reverses immune dysfunction and hepatitis $\mathrm{B}$ viral persistence in a mouse animal model. PloS One. 2012;7(6):e39179. Doi: https://doi.org/10.1371/journal.pone.0039179

56. Gardiner D, Lalezari J, Lawitz E, et al. A randomized, double-blind, placebo-controlled assessment of BMS-936558, a fully human monoclonal antibody to programmed death-1 (PD-1), in patients with chronic hepatitis $\mathrm{C}$ virus infection. PloS One. 2013;8(5):e63818. Doi: https://doi. org/10.1371/journal.pone.0063818

57. Biron CA, Brossay L. NK cells and NKT cells in innate defense against viral infections. Curr Opin Immunol. 2001;13(4):458-64. Doi: https://doi.org/10.1016/S09527915(00)00241-7

58. Mondelli MU, Varchetta S, Oliviero B. Natural killer cells in viral hepatitis: facts and controversies. Eur J Clin Invest. 2010;40(9):851-63. Doi: https://doi.org/10.1111/j.13652362.2010.02332.x

59. Peppa D, Gill US, Reynolds G, et al. Up-regulation of a death receptor renders antiviral $\mathrm{T}$ cells susceptible to NK cell-mediated deletion. J Exp Med. 2013;210(1):99-114. Doi: https://doi.org/10.1084/jem.20121172

60. Tjwa ETTL, van Oord GW, Hegmans JP, et al. Viral load reduction improves activation and function of natural killer cells in patients with chronic hepatitis B. J Hepatol. 2011;54(2):209-18. Doi: https://doi.org/10.1016/j. jhep.2010.07.009

61. Liang TJ, Block TM, McMahon BJ, et al. Present and future therapies of hepatitis B: from discovery to cure. Hepatology. 2015;62(6):1893-908. Doi: https://doi.org/10.1002/ hep. 28025

62. Lempp FA, Urban S. Inhibitors of hepatitis B virus attachment and entry. Intervirology. 2014;57(3-4):151-7. Doi: https://doi.org/10.1159/000360948

63. Schulze A, Gripon P, Urban S. Hepatitis B virus infection initiates with a large surface protein-dependent binding to heparan sulfate proteoglycans. Hepatology. 2007;46(6):175968. Doi: https://doi.org/10.1002/hep.21896

64. Koumbi L. Current and future antiviral drug therapies of hepatitis B chronic infection. World J Hepatol. 2015;7(8):103040. Doi: https://doi.org/10.4254/wjh.v7.i8.1030

65. Gish RG, Yuen M-F, Chan HLY, et al. Synthetic RNAi triggers and their use in chronic hepatitis B therapies with curative intent. Antiviral Res. 2015;121:97-108. Doi: https://doi.org/10.1016/j.antiviral.2015.06.019

66. Maepa MB, Roelofse I, Ely A, et al. Progress and Prospects of anti-HBV gene therapy development. Int J Mol Sci. 2015;16(8):17589-610. Doi: https://doi.org/10.3390/ ijms 160817589 
67. Zhang Z, Vu G-P, Gong H, et al. Engineered external guide sequences are highly effective in inhibiting gene expression and replication of hepatitis B virus in cultured cells. PloS One. 2013;8(6):e65268. Doi: https://doi.org/10.1371/ journal.pone.0065268

68. Xia C, Chen Y-C, Gong $\mathrm{H}$, et al. Inhibition of hepatitis B virus gene expression and replication by ribonuclease $\mathrm{P}$. Mol Ther J Am Soc Gene Ther. 2013;21(5):995-1003. Doi: https://doi.org/10.1038/mt.2013.37

69. Cradick TJ, Keck K, Bradshaw S, et al. Zinc-finger nucleases as a novel therapeutic strategy for targeting hepatitis B virus DNAs. Mol Ther J Am Soc Gene Ther. 2010;18(5):947-54. Doi: https://doi.org/10.1038/mt.2010.20

70. Weber ND, Stone D, Sedlak RH, et al. AAV-mediated delivery of zinc finger nucleases targeting hepatitis $\mathrm{B}$ virus inhibits active replication. PloS One. 2014;9(5):e97579. Doi: https://doi.org/10.1371/journal.pone.0097579
71. Bloom K, Ely A, Mussolino C, et al. Inactivation of hepatitis $\mathrm{B}$ virus replication in cultured cells and in vivo with engineered transcription activator-like effector nucleases. Mol Ther. 2013;21(10):1889-97. Doi: https://doi. org/10.1038/mt.2013.170

72. Dong $\mathrm{C}, \mathrm{Qu} \mathrm{L}$, Wang $\mathrm{H}$, et al. Targeting hepatitis $\mathrm{B}$ virus cccDNA by CRISPR/Cas9 nuclease efficiently inhibits viral replication. Antiviral Res. 2015;118:110-7. Doi: https:// doi.org/10.1016/j.antiviral.2015.03.015

73. Hu Y, Cheng X, Cao F, et al. $\beta$-Thujaplicinol inhibits hepatitis $B$ virus replication by blocking the viral ribonuclease $\mathrm{H}$ activity. Antiviral Res. 2013;99(3):221-9. Doi: https://doi. org/10.1016/j.antiviral.2013.06.007

74. Tavis JE, Lomonosova E. The hepatitis B virus ribonuclease $\mathrm{H}$ as a drug target. Antiviral Res. 2015;118:132-8. Doi: https://doi.org/10.1016/j.antiviral.2015.04.002 